\title{
Little Britain? The Debate on Britain's Foreign and Defence Policy
}

Une Grande-Bretagne isolationniste? Le débat sur les politiques étrangère et de défense

\section{Thibaud Harrois}

\section{(2) OpenEdition}

\section{Journals}

Electronic version

URL: http://journals.openedition.org/rfcb/580

DOI: $10.4000 /$ rfcb.580

ISSN: 2429-4373

Publisher

CRECIB - Centre de recherche et d'études en civilisation britannique

Electronic reference

Thibaud Harrois, "Little Britain? The Debate on Britain's Foreign and Defence Policy ", Revue Française de Civilisation Britannique [Online], XX-3 | 2015, Online since 01 December 2015, connection on 30 April 2019. URL : http://journals.openedition.org/rfcb/580 ; DOI : 10.4000/rfcb.580

This text was automatically generated on 30 April 2019.

\section{c)}

Revue française de civilisation britannique est mis à disposition selon les termes de la licence Creative Commons Attribution - Pas d'Utilisation Commerciale - Pas de Modification 4.0 International. 


\title{
Little Britain? The Debate on Britain's Foreign and Defence Policy
}

\author{
Une Grande-Bretagne isolationniste? Le débat sur les politiques étrangère et de \\ défense
}

Thibaud Harrois

\section{Introduction}

Foreign and defence policy is not a central issue in British general elections and the 2015 general election campaign was no exception, with the issue being mentioned only at the end of party manifestos and with few debates on the subject. Yet, whereas there usually is much common ground between the policies of government and the Opposition, the 2015 debate was of a different kind. On the one hand, the Conservatives argued that David Cameron's government had pursued the same "grand strategy" as the one the UK had pursued since the end of the Cold War, that Britain is still "punching above her weight" on the world stage and one of the most powerful countries in Europe as well as the USA's strongest ally. On the other hand, the Opposition agreed with many experts, military officials or foreign politicians who voiced their concerns in the media, to say that Britain had seen a decline in its international role and influence during Cameron's premiership.

The debate on Britain's waning influence in the world is not a new one, but while it had been somewhat settled at the beginning of Blair's premiership, it has come back with a vengeance when the UK failed to win the peace after its long interventions in Afghanistan and Iraq. The 2011 military intervention in Libya, which was overwhelmingly supported by Parliament and the public, was not sufficient to erase doubts about the role of the Armed Forces after they left Afghanistan and they underwent deep budgetary cuts. Besides, the Opposition embraced the public's growing war-weary caution on the use of force in an ever more complex international environment, especially when these actions were not undertaken under a clear UNSC mandate. 
Thus this paper aims to examine the gap between David Cameron's - and Ed Miliband's speeches in which they stated their wish to see Britain continuing to play the role of a great power, and the failing support for involvement in foreign operations.

The debate on whether to intervene, either in Libya or in Syria (against the Assad regime or against ISIL), revolved around the questions of legality and legitimacy of such military interventions. The arguments put forward by the government and those who have supported intervention from August 2013 will be contrasted with the arguments used by Ed Miliband and MPs who have been more cautious about the use of force in order to show their respective understanding of the role of the UK in the world and the limits of British interventionism.

The gap between the image political leaders have of the country's role in the world and Britain's actual commitments can also be explained by the cuts in the defence budget made by the Coalition government. The debate on the need for further cuts and their consequences on Britain's military ambition will thus be explored.

Lastly, the consequences of the Conservatives' victory on 7 May will open a new debate on the need for an overarching national strategy that includes a clear definition of British interests and takes into account the country's capacity to deal with new threats, especially from the Middle East. The kinds of domestic and international pressures that are exercised on Britain will be analysed to offer some insight on the challenges the new government will have to face.

\section{The coalition government, Parliament, and the debate on British military interventions}

Britain's role in the world has rarely been as debated inside the walls of Parliament as during Cameron's first term in office. The "royal prerogative" gives the Prime Minister vast powers and the Westminster model has long been used in foreign policy analyses to explain why the issue is so rarely debated in the House of Commons and in the House of Lords. However, building on James Strong's article, ${ }^{1}$ I argue that Parliament has been given more power on foreign and defence policy in the last decade and that, under the last government, it has become the place for an actual debate on the UK's foreign interventions. The Conservatives' justification for the war in Libya and the proposed interventions in Syria and against ISIL as well as the Opposition's stance on each of these issues are part of a pre-electoral debate in which the two main parties stated their vision of Britain's role in the world.

\section{Parliamentary debates on Britain's foreign and defence policy}

Traditionally, the British Parliament has not had any role in decisions to use military force as the Westminster model vests the responsibility to deploy armed forces in the Prime Minister, who possesses the "royal prerogative". Most of the foreign and defence policy debates organised in the House of Commons are adjournment debates ${ }^{2}$, that allow MPs to discuss policies but without voting on them, and Parliament spends but a very limited amount of time discussing the issue, both because it is an issue that requires few laws and because there is often a consensus between party leaders. Studies on foreign and defence policy generally emphasise the bipartisan approach to the issue, ${ }^{3}$ although this 
apparent cross-bench consensus sometimes diverts attention from deeper tensions between leaders and their own back-benchers. However, party discipline is such that MPs most often remain loyal to the choices made by the government and authors dismiss parliamentary discussions, be they intra- or inter-party, as irrelevant in the policymaking process.

However, since the March 2003 vote over the Iraq war, Parliament has played a greater role, which gave rise to a renewed analysis of the policy-making process that underlines the fact that a government necessarily has to negotiate in order to gather support for its action, including in the field of foreign and defence policy. The "differentiated policy model" ${ }^{4}$ thus challenges the traditional Westminster model and offers useful tools to explain the changes made to the royal prerogative. This also led some authors to talk about a new parliamentary prerogative, especially when analysing the power to take Britain to war. ${ }^{5}$ In March 2011, in the context of the war in Libya, William Hague, then Foreign Secretary, committed to "enshrine in law for the future the necessity of consulting Parliament on military action". ${ }^{6}$ Such a law failed to be adopted, but the new Cabinet Manual mentioned the rise of a convention giving the House of Commons an opportunity to organise a debate before troops are sent abroad. ${ }^{7}$

The growing role of Parliament in the last decade has had a direct impact on the policy of the Conservative-led coalition, and on the attitude of the Labour opposition between 2010 and 2015 as well as during the 2015 campaign. The arguments used during the debate on the war in Libya and those that led Parliament to deny the Prime Minister authorisation to send British armed forces to Syria can be contrasted to understand in what conditions and for what reasons each party is ready to commit British troops to war.

\section{Meeting the conditions for intervention: the 2011 war in Libya}

The decision to go to war in Libya was justified by the need to save the lives of civil protesters threatened by the violent repression of demonstrations by Colonel Muammar Gaddafi. Following the adoption of the United Nations Security Council Resolution 1970 on 26 February 2011, France and Britain played a frontline role in the process that led to the adoption on 17 March 2011 of UNSC Resolution 1973 that allowed the use of "all necessary means" in order to protect civilians from Gaddafi's forces. ${ }^{8}$ The threat of a massacre in Benghazi, the international support for military action - both through adoption of Resolution 1973 and the call for the implementation of a no-fly zone from the Arab League - helped David Cameron and William Hague make the case for intervention in Westminster. In order to get parliamentary support, they argued that Britain would not take any unilateral action and was working with partners in order to obtain a clear mandate, which would remove any doubt on the legality of the intervention. Ministers also guaranteed that the government would not launch a military intervention without seeking parliamentary approval. ${ }^{9}$ After resolution 1973 was adopted, Britain launched "Operation Ellamy" on 19 March 2011. Two days later in Parliament, Cameron made the case for war, insisting on the moral need to protect innocent civilians and on the fact that no ground troops would be sent to Libya, ${ }^{10}$ making it clear that "this [was] not another Iraq ."11 MPs approved the motion by 557 votes to 13 . However, the process that led to the intervention in Libya being overwhelmingly approved by Parliament was soon to become synonymous with a loss of power on the part of the Prime Minister, and as another 
humanitarian crisis unfolded in the Middle East, the government was unable to make the case for another war in the region.

\section{The debate on interventions in Syria and against ISIL: the end of the age of British interventionism?}

A few months after Gaddafi was ousted from power and killed by rebels in Sirte, attention focused on the ongoing civil war in Syria. But as the need for intervention was being debated in the media, William Hague made clear in June 2013 that neither arms nor British forces would be sent to Syria without previous parliamentary approval. ${ }^{12}$ On 21 August, a chemical weapons attack on the suburbs of Damascus allowed Cameron to build a clearer case against the Assad regime ${ }^{13}$ and the Prime Minister recalled Parliament before the end of the summer recess in order to organise a vote on military action. However, Ed Miliband insisted on the fact that UN inspectors had not yet established Assad's responsibility for the attack, and that he therefore could not support the government's motion. Even after the PM said he would wait for the full report by UN weapons inspectors before seeking approval for a British intervention, ${ }^{14}$ the Labour leader chose to withdraw his support for the government's motion, which was subsequently defeated by 285 votes to 272 on 29 August 2013. Contrary to what had happened during the run-up to the war in Libya, MPs began to question the legality and the legitimacy of an intervention that was not backed by the UN Security Council. Besides, Cameron failed to convince his own MPs, thirty of whom voted with Labour (together with nine Liberal Democrats), and lost control of his foreign policy to Parliament.

The British decision not to commit troops led the USA to suspend its move towards intervention and allowed Russia to make a deal with Assad requiring him to destroy Syrian chemical weapons. At a national level, Cameron's statement confirmed the birth of a new constitutional convention that required Parliament to approve military action. ${ }^{15}$ It also considerably shook the Conservatives' confidence in their leader, even though the party rebels confirmed they supported the PM on other social policies. ${ }^{16} \mathrm{Ed}$ Miliband, whose leadership had been heavily criticised during the summer, was praised by Labour MPs and the media for his commitment to international law and diplomacy against Cameron's more hawkish behaviour. ${ }^{17}$. However, the Labour leader was also blamed for the international consequences of the vote, with Britain losing its forefront role on the international stage, especially after Cameron ruled out the possibility of another vote on Syria. ${ }^{18}$ In the end, the aftermath of the vote seemed more negative than positive for Ed Miliband's leadership as concerns were voiced as to the kind of foreign policy a Labour government would implement. ${ }^{19}$

One year later, on 26 September 2014, the House of Commons voted in favour of air strikes against ISIL in Iraq by a vote of 524 to 43 , thus launching the third operation in Iraq in 25 years. There being no UN mandate authorising intervention against ISIL, Cameron managed to convince Miliband and the vast majority of MPs to support military action by insisting on the fact that no ground troops would be sent to Iraq and that British forces' mission was to support the Iraqi government in its effort to free itself from ISIL. ${ }^{20}$ However, in spite of ISIL being present both in Iraq and Syria, Cameron chose to limit the scope of the motion to Iraq in order not to trigger opposition from Miliband and 
Labour MPs. ${ }^{21}$ Further military engagement would need a new vote in Parliament should the government wish to intervene in Syria.

Thus, even though the new convention has not been enshrined in law, no government will be able to launch a military intervention without prior parliamentary approval. This might make intervention more difficult as the public - and the Commons - have become more sceptical about the reasons for intervention. Ed Miliband has made it clear his party would support no intervention that would not have been previously authorised and legitimised by a UNSC resolution. Therefore the arguments used during the parliamentary debates on whether to intervene in Libya, Syria or against ISIL give a preelection campaign insight on the way the main parties and their leaders think about British interventionism and the UK's role in the world.

\section{Britain in the world: what means for what ambitions?}

By refusing to organise a second vote on a possible intervention in Syria after the Labour party voted the first motion down, the Prime Minister hoped to put the responsibility for non-intervention on the shoulders of those who had opposed him. However, Ed Miliband insisted Labour would have supported intervention if it had been legitimised by a UNSC resolution and accused the government of being responsible for Britain's isolationism. But in his attempt to re-establish the Conservative Party's reputation as the "party of defence", Cameron argued that only the Conservatives had a clear plan to maintain Britain's international rank. The prospect of a Labour-SNP pact of government provided the Conservatives with an opportunity to effectively use defence and more particularly Trident renewal to open a debate on Labour's ability to make reasonable choices for the future of the country, an argument they also used when Cameron moved the debate back on the economy.

\section{Labour's opposition to "small-minded isolationism"}

Ed Miliband's major speech on foreign policy was given on 24 April 2015. In that speech, the Labour leader accused David Cameron of having led a policy of "small-minded isolationism":

David Cameron has presided over the biggest loss of influence for our country in a generation. And that has happened because the government he leads has stepped away from the world, rather than confidently towards it. It is an approach that has shrunk our influence and weakened Britain. ${ }^{22}$

Miliband pointed out several occasions when Britain's "isolation and waning influence" in the world was made obvious. First, a few weeks before the speech was made, on 11 February 2015, Britain had been absent from the Minsk II summit that had gathered the leaders of Ukraine, Russia, France and Germany in order to agree on new measures to solve the crisis in the Donbass region of Ukraine. The second example of Britain's failure under the Conservative-led government was Libya. Miliband accused the government of misreading the situation on the ground before the intervention, and leaving Libya to its own devices instead of helping the Libyans build a stable government after October 2011. The third and "most important cause of [Britain's] loss of influence" is the ambivalent discourse of the Conservatives on Britain's future in the European Union. Without a clear 
commitment to staying in the EU, Britain's influence would necessarily be diminished " and our loss of influence in Europe leads to a further loss of influence in the world." ${ }^{23}$

Ed Miliband's foreign policy experience as Leader of the Opposition before the 2015 elections had been limited and his positions unclear. Whereas his brother David had been Foreign Secretary in Gordon Brown's government, Ed had been in charge of Energy and Climate Change which gave him far less international experience and even after he became party leader, his flight record was far from outstanding ${ }^{24}$ and there were lasting concerns about his vision for Britain in the world after his opposition to intervention in Syria. However, his speech allowed him to state that he would support "genuine and hardheaded multilateralism" and "international law" in case Britain should intervene. He also insisted on the importance of working with EU and NATO partners to restore British influence in international organisations and in the world. The Labour Manifesto insisted in the same fashion on Britain's "unique influence in the world" and Labour's pledge to "take a multilateral approach to global challenges." 25

Besides, Miliband linked defence policy with the rest of his economic pledges:

I want to be absolutely clear that amongst the reasons we reject the extreme spending cuts that the Conservative Party propose is that they would be truly catastrophic for the future of our armed forces [...] I am not going to sacrifice the defence of our country on an ideological commitment to a significantly smaller state.

The Labour manifesto made the same commitment to:

ensuring the UK has responsive, high-tech Armed Forces, with the capability to respond to emerging, interconnected threats, in an unpredictable landscape. We will conduct a Strategic Defence and Security Review in the first year of government, with an inclusive national debate on the security and defence challenges facing the country. ${ }^{26}$

The coalition government had proposed to hold a new SDSR every five years ${ }^{27}$ (a period that was judged far more appropriate than the twelve years between the previous review and the 2010 SDSR. ${ }^{28}$ The Labour Party agreed with the proposed timetable and was ready to conduct the process immediately after the election. However, the manifesto insisted that the review be both "fiscally responsible and strategically driven", and not "Treasurydriven" as the 2010 Review had been.

However, Ed Miliband's effort to convince voters that Cameron's government was to blame for the UK's loss of influence in the world did not really trigger the expected debate on defence. The issue became more central in the campaign when Labour's expected alliance with the SNP raised doubts about the future of Trident.

\section{Trident renewal and the campaign: party commitments and the ambiguity of a Labour-SNP alliance}

At the beginning of his time as Labour leader, Ed Miliband adopted a cautious approach to Trident, saying that the UK needed "to look very carefully at whether renewing Trident is the necessary or the right thing to do." ${ }^{29}$ However, after the government published the Trident Alternatives Review ${ }^{30}$ and confirmed the country's commitment to Trident renewal, the Labour Party reaffirmed its commitment to Britain's nuclear capability and the last pledge in the defence section of the Labour manifesto stated that the party "[remained] committed to a minimum, credible, independent nuclear capability, delivered through a Continuous At-Sea Deterrent." ${ }^{31}$ 
It is surprising that an issue on which the two main parties agree should become the focus of public attention during the campaign, and the only defence-related issue to be discussed at length in the media. Yet, as polls suggested Labour would be able to form a government only if they agreed on some sort of coalition pact with the Scottish National Party, Conservative senior figures suggested this would inevitably lead to Trident being abandoned. Indeed, the SNP manifesto stated:

The SDSR must [...] consider the advantages of a defence policy without weapons of mass destruction and wasting £100bn renewing Trident. We will continue in our principled opposition to nuclear weapons and believe that the UK should abandon plans to renew the Trident nuclear missile system. ${ }^{32}$

Nicola Sturgeon made this measure a red line in any negotiation to form a coalition government, thus confirming the SNP's traditional opposition to what is often perceived not only as a waste of money but also a typical example of the kind of policies London imposes on the Scottish territory and people. The SNP's fierce opposition to Trident led many to wonder what the Labour Party would do in case it had to form a coalition government that included or partnered with Scottish nationalist MPs. The debate was used by the SNP and the Labour Party to show their difference and convince voters that if the SNP supported a minority Labour government, this did not mean that one party was adopting all of the other party's policies or that the two parties' stances would be mixed in order to reach a vague, middle of the road compromise. Yet however much Miliband insisted that if he formed a government with the support of the SNP he would nonetheless maintain Britain's deterrent, he failed to explain how a Labour-SNP deal could lead to a stable and disciplined government. Douglas Alexander's reaffirmed that " Labour's commitment to continuous at-sea nuclear deterrent was not up for negotiation." 33 However, on the same day, Defence Minister Michael Fallon wrote that Ed Miliband was " willing to stab the United Kingdom in the back to become Prime Minister" in the same way he did his brother to gain the Labour leadership. ${ }^{34}$ The personal nature of the attack caused some stir, including among Conservatives, but David Cameron supported Fallon and repeated that the Labour party was "playing fast and loose with our security". ${ }^{35}$ Even when Vernon Coaker, the Labour defence spokesman, argued that the Labour party was indeed committed to Trident renewal and asked whether the Conservatives would support Labour in a vote on the issue, Fallon replied that "the way to be absolutely sure about our nuclear defence is to vote Conservative." ${ }^{36}$

Thus the Conservatives' response to Miliband mixed personal attacks on the Labour leader with worries about the party's ability to effectively undertake the necessary measures to secure the future of the UK's nuclear capability. Whereas there have been very few - if any - past examples of a general election debate when defence became a decisive issue, the 2015 campaign showed that a change in the parliamentary majority could now have consequences on an issue that used to be characterised by continuity. The Conservatives therefore insisted on the difficulties that the country could expect if a Labour-SNP coalition were brought to power. They further insisted on Labour's inconsistent defence policy plans as part of a wider attack on the economic unsoundness and strategic ambiguity in Labour's manifesto.

\section{The Conservative Party: putting the economy first}

Just as Lynton Crosby, the Conservative campaign director, kept repeating that the Conservatives were the only party to have a "long-term economic plan", the party's line of 
attack on defence was also the economy. The coalition government had prepared the 2010 National Security Strategy (NSS) and SDSR, which were published at the same time as the Comprehensive Spending Review (CSR), and there were clear indications in the SDSR that the government's main concern had been to balance the book and that the defence budget was no exception. ${ }^{37}$ Former Defence Secretary Liam Fox adds that the coalition government was often accused of having produced a "Treasury-driven" review but that it was the only solution to tackle the deficit in public expenditure inherited from the previous Labour government. The over-commitment was estimated at $£ 38$ billion but it was even bigger than that according to Fox, who adds that many problems were made worse by the bad governance of the MoD with no mechanism to say whether the targets were right and whether they were achievable. ${ }^{38}$

The 2015 Conservative Manifesto insisted once more on the situation the government inherited when they came to power in 2010:

Labour's Great Recession weakened Britain on the world stage. They left a £38 billion black hole in the defence budget, went 12 years without conducting a Strategic Defence Review, and, at time, failed to provide our Armed Forces with the equipment they needed in Afghanistan. They shut down over 30 British diplomatic missions, failed to plan properly for Iraq's reconstruction, ignored trade and investment opportunities overseas, and neglected vital relationships. ${ }^{39}$

Labour's bad management had made cuts in the defence budget necessary and had threatened Britain's national security as a whole. On the contrary, the Conservatives pledged to "maintain a balanced defence budget" and provide the "equipment they need" to the Armed Forces:

We can only have strong, well-funded Armed Forces by continuing to build a stronger economy. We have the second largest defence budget in NATO and the largest in the EU. We are meeting NATO's two targets: that each country should spend two per cent of its gross national income on defence, and of that spending 20 per cent should go on major equipment. ${ }^{40}$

Thus the Conservatives insisted they had made and would continue to make well-planned investments in defence capabilities. However, since the end of the Cold War, British military interventions have all taken place within a coalition (NATO or US-led) and the November 2010 Lancaster House Treaties are a sign of Britain's (and France's) evergrowing difficulty maintaining and modernising their armed forces on their own. Cooperation with other nations, France in particular, seems a necessary move if Britain is to maintain her international rank, especially at a time when the "special relationship" does not bring as much as it used to for Britain. Indeed, voters expect their country to continue to exercise influence in the world and play the role of a bridge between the USA and Europe.

\section{The voters' paradox: expecting Britain to do more with less}

The 2015 party manifestos provide yet another proof that issues such as the economy, taxes, health, crime and justice or education are more crucial to the electoral debate than foreign and defence policy, which is relegated at the end of the documents. Yet, even if foreign and defence policy was unlikely to become a decisive issue, polls suggest that there is no consensus among Britons on the country's role in the world. A major survey was conducted by Chatham House and YouGov in July and August 2014 and published in January $2015 .{ }^{41}$ It reveals that a majority of Britons support an ambitious foreign policy, 
with more than $60 \%$ of Britons saying that the country should aspire to be a "great power" and a majority saying that Britain should participate in peacekeeping missions and should help maintain international security. However, Britons generally identify border protection and counterterrorism as the most important international issues, and only $17 \%$ of the public say that it is a moral responsibility to support revolutions and uprisings against dictators. Besides, while two-thirds of Liberal Democrats and half of Labour voters say they support an ethical foreign policy, only one-third of Conservatives do. Thus, even though Britons still have "great power expectations" for the UK in the world, they have become more supportive of a defensive policy that aims to protect the nation's borders and homeland security.

Furthermore, in spite of the support for the UK's leadership role and responsibilities in the world, $60 \%$ of the public agree that "The UK is expected to do too much internationally [and that it] should do less and others should do more". Britons are divided on questions of defence spending: $33 \%$ of the public would like defence spending to increase, $31 \%$ want to keep spending at current levels and $22 \%$ would favour cuts. While Trident was not part of the 2014-2015 survey, a 2013 survey shows that $32 \%$ of the electorate wanted to maintain the Trident nuclear weapons system, $34 \%$ wanted to find a cheaper system and $20 \%$ favoured scrapping Trident altogether. ${ }^{42}$

Surveys thus reveal that Britons are not becoming isolationists, but they favour foreign interventions that are meant to improve national security and which are in Britain's interest rather than humanitarian interventions that are part of an "ethical" foreign policy. Besides, more Britons would rather have the government spending the same amount or less on defence, thus putting politicians in a paradoxical situation where they are expected to satisfy voters' ambitious vision for the UK while continuing to cut spending. The 2010 SDSR and NSS focused on the latter expectation and the election of a Conservative government on 7 May 2015 is likely to lead the country towards another “Treasury-led" strategy.

\section{Britain's foreign and defence policy after 7 May 2015}

The newly-elected Conservative government pledged to put the economy first while maintaining a certain level of defence spending in order to continue to be able to face international threats on Britain's security. Thus the government faces several challenges at the same time. At the domestic level, the government will have to deal with the need to fulfil its pledge to continue to curb the deficit, while responding to voters' "great power expectations" for Britain. But the government is also under international pressure as the USA and other European allies want the UK to continue to take its share of the burden by spending a minimum of $2 \%$ of its GDP on defence. How the government plans to meet these challenges will be detailed in the new NSS and SDSR to be published in the second half of 2015, together with a new spending review.

\section{The "triple lock" pledge on defence: NATO allies and the 2015 election}

At the NATO Summit that took place in Wales on 4-5 September 2014, the UK government encouraged all member states to meet the Organisation's $2 \%$ target of GDP spending on defence. However, even if, as Michael Fallon underlined in a campaign speech ${ }^{43}$ Britain “ 
[has] met and will this year again meet the 2 per cent target", the chancellor, George Osborne, announced as early as November 2014 that deeper cuts were to affect the army as he needed to make more savings in order to meet his austerity targets. ${ }^{44}$ Spending plans and growth projections put defence spending at an estimated 1.88\% of GDP in 2015-16, thus falling below the NATO $2 \%$ target for the first time. The chief of the defence staff, General Sir Nick Houghton, expressed his worries and declared that further cuts in funding and in the number of troops could threaten the national security and would jeopardise the armed forces. ${ }^{45}$ Twenty-seven Conservative MPs, including former defence secretary Sir Malcolm Rifkind and Rory Stewart, the chairman of the Commons Defence Select Committee, also called on the government to meet the NATO target, forcing a Commons vote on the issue a few weeks before the election. ${ }^{46}$ But David Cameron is not being put under pressure to meet the $2 \%$ target at home only. Indeed, during Cameron's trip to the USA in January 2015, President Obama insisted that the military alliance between the two countries would be undermined if Britain did not take its share of the burden, and US defence officials have intensely lobbied the British ambassador with the same message. ${ }^{47}$

Michael Fallon tried to reassure both voters and Britain's allies with the promise of a " triple lock" on defence:

First, we commit to increasing the defence equipment budget by at least 1 per cent more than inflation, throughout the Parliament [...]. Second, we commit to making no further reductions in the size of our regular armed forces. Third, we commit to modernising our independent nuclear deterrent [...].48

However, neither Fallon nor Cameron made any formal commitment to spending $2 \%$ of GDP on defence, whereas the government enshrined their commitment to spending $0.7 \%$ of GDP on international aid in law, something Liam Fox found "hard to swallow". How the government will fulfil the "triple lock" pledge without spending $2 \%$ of GDP on defence is unclear and given the Conservatives' promise to continue fighting the deficit, the next SDSR will prove a difficult process.

\section{The 2015 NSS, SDSR and CSR: a missed opportunity to debate the government's choices}

The end of operations in Afghanistan and the new challenges to Britain's security, from terrorism to Russia, require Britain to redefine its world vision and the role of its armed forces. The 2010 SDSR and NSS had been conducted over a few months, which had given rise to concerns about the speed of the process and the poor quality of the strategic thinking that had guided those who were in charge of conducting it. ${ }^{49}$ Furthermore, in order to build a clearer strategy for Britain and a coherent DSR, the Commons Defence Committee recommended that the NSS process start earlier and be published ahead of the CSR and SDSR..$^{50}$ However, a few months before the general election and six months before the publication of the next NSS, no formal talks had been held and there were concerns that if anything were done it would again be far too rushed to be out before the next CSR. ${ }^{51}$ Besides, a rushed NSS and SDSR process will restrain the number of people academics, civil servants, politicians or members of the Armed Forces - consulted when preparing the strategy, which might damage the quality of the process. ${ }^{52}$ In 2010 , the newly created National Security Council had been in charge of the process and there had been limited consultation, something which the Defence Committee had found " regrettable." ${ }^{53}$ The Committee was particularly concerned that, because of the lack of consultation, the public would fail to understand the decisions made by the government, 
which would create a "sense of disconnection between the decisions of government and the understanding of the people at large on defence issues." ${ }^{54}$ By conducting another speedy process, the newly re-elected Conservative government is likely to reinforce this sense of disconnection, and deprive the country of a rare opportunity to debate Britain's foreign and defence policy. One conclusion that can be drawn from this is that in spite of all the talks and pledges about maintaining Britain's role in the world, the Conservatives Party under Cameron did not see foreign and defence policy as a critical electoral issue or a priority for the nation. This also reveals the deep consequences of the financial crisis and ensuing austerity measures on Conservative politics. The Conservative Party had long prided itself on being the "party of defence" that held an interventionist and militaristic policy under Margaret Thatcher and criticised Labour's inadequate funding of the armed forces, but this tradition has given way to a more isolationist view that focuses on the defence of the UK's borders and territory, more in tune with voters' war-weary attitude after decades of foreign interventions.

\section{Conclusion}

The debate on Britain's role in the world and the end of interventionism started before the 2015 general election. Indeed, while Parliament used to play but a very limited role in the policymaking process, the last decade has seen the evolution of the royal prerogative and the emergence of a new parliamentary prerogative, which gave MPs the power to approve the Prime Minister's decision to intervene in Libya and deny him the right to send planes to Syria. The Opposition focused on the legality and legitimacy of the proposed intervention in Syria, thus announcing the arguments that Ed Miliband later used during the campaign to present his version of interventionism. However, the focus of the campaign was on the country's economic difficulties and their link with the United Kingdom's military and diplomatic decline. Both parties tried to woo voters by promising to maintain Britain's "world power" ambition while continuing to cut the budget deficit, which would require efforts from all departments, including the MoD. The way the new Conservative government fulfils its election pledges will depend on the new Strategy it is expected to formulate at the end 2015.

\section{BIBLIOGRAPHY}

BALE, Tim. Five Year Mission: The Labour Party under Ed Miliband. Oxford: Oxford University Press, 2015, 320p.

BEVIR, Mark \& RHODES, R A. W. « Les récits du régime politique britannique », Revue française de science politique, vol. 49, $\mathrm{n}^{\circ} 3$, juin 1999, pp. 355-378.

BRADSHAW, Ben. 'On Syria, we have allowed Labour policy to be dictated by the government'. The Guardian. 5 Sep 2013. 
CABINET OFFICE. The Cabinet Manual: A guide to laws, conventions and rules on the operation of government. $1^{\text {st }}$ ed. London: Cabinet Office, 2011, 107p.

CAMERON, David. Statement on Libya. House of Commons. London. 28 Feb 2011.

CONSERVATIVE PARTY. Strong Leadership, A Clear Economic Plan, A Brighter, More Secure Future: The Conservative Party Manifesto 2015. London: The Conservative Party, 2015, 81p.

COUGHLIN, Con \& SWINFORD, Steven. 'US military chief: Britain cannot cut more troops'. The Daily Telegraph. 1 Mar 2015.

Defence and Security Election Debate. BBC Two. 28 Apr 2015

DOMINICZAK Peter, ROSS Tim \& WINNETT Robert. 'Cameron backs down on urgent Syria strikes'. The Daily Telegraph. 28 Aug 2013.

FALLON, Michael. ‘This unholy alliance would put Britain's security in jeopardy'. The Times. 9 Apr 2015.

---. 'A Conservative Party View of UK Defence Policy'. Speech. Royal United Service Institute, London. 10 Apr 2015.

FARMER, Ben. 'Obama to Cameron: maintain UK defence spending or weaken Nato'. The Daily Telegraph. 10 Feb 2015.

GASKARTH, Jamie. British Foreign Policy. Cambridge: Polity Press, 2013, 271p.

GILES, Chris. 'Britain and the cuts: Blow for Cameron as UK faces deeper cuts'. Financial Times. 10 Nov 2014.

GRICE, Andrew. 'Lid Dems push for "stand-by" Trident replacement deal'. The Independent. 19 Jul 2012.

HAGUE, William. Interview. “The Andrew Marr Show”. BBC. 9 Jun 2013.

House of Commons Debates, 7 Mar 2011, vol. 524, col. 644.

---. 10 Mar 2011, vol. 524, col. 1066.

---. 21 Mar 2011, vol. 525, col. 700-806.

---. 29 Aug 2013, vol. 566, col. 1555-1556.

---. 26 Sep 2014, vol. 585, col. 1255.

HM GOVERNMENT. Securing Britain in an Age of Uncertainty: The Strategic Defence and Security Review .Cm 7948. London: The Stationery Office, 2010, 76p.

HOUGHTON, N. Interview. Andrew Marr Show. BBC. 9 Nov 2014.

HOUSE OF COMMONS DEFENCE COMMITTEE. The Strategic Defence and Security Review. HC 345. London: The Stationery Office, 2010.

---. The Strategic Defence and Security Review and the National Security Strategy. HC 761. London: The Stationery Office, 2011.

---. Towards the next Defence and Security Review: Part One. vol. 1. HC 197. London: The Stationery Office, 2014.

---. The situation in Iraq and Syria and the response to al-Dawla al-Islamiya fi al-Iraq al-Sham (DAESH). HC 690. London: The Stationery Office, 2015.

HOUSE OF COMMONS PUBLIC ADMINISTRATION SELECT COMMITTEE. Taming the Prerogative: Strengthening Ministerial Accountability to Parliament. HC 422. London: HMSO, 2004. 
---. Who does UK National Strategy? HC 435. London: The Stationery Office, 2010.

HOUSE OF LORDS SELECT COMMITTEE ON THE CONSTITUTION. Waging War: Parliament's role and responsibility. HL 236. 2006.

JOINT INTELLIGENCE ORGANISATION (CABINET OFFICE). 'Syria: Reported Chemical Weapons Use'. Letter to the Prime Minister. 29 Aug 2013.

JOSEPH, Rosara. The War Prerogative: History, Reform and Constitutional Design. Oxford: Oxford University Press, 2013, 242p.

LABOUR PARTY. Britain can be better: The Labour Party Manifesto 2015. London: Labour Party, 2015, $83 p$.

'Libya protests: Defiant Gaddafi refuses to quit'. BBC News. 22 Feb 2011.

MASON, Rowena. 'Ed Miliband restores party confidence in his leadership on Syria motion'. The Guardian. 30 Aug 2013.

MILIBAND, Ed. 'Britain's Place in the World: A Labour Perspective'. Speech. London, Chatham House. 24 Apr 2015.

MINISTRY OF JUSTICE. The Governance of Britain: War powers and treaties: Limiting executive powers, Cm 7239. London, HMSO, 2007.

---. The Governance of Britain - Constitutional Renewal. Cm 7342-I. London: HMSO, 2008.

'Nato 2\% defence spending target should be met, MPs say’. BBC News. 12 Mar 2015.

'National security strategy “will be rushed”'. BBC News. 3 Mar 2015.

NORTON, Philip. Parliament in British Politics. $2^{\text {nd }}$ ed. Basingstoke: Palgrave Macmillan, 2013, 352p.

RAINES, Thomas. Internationalism or Isolationism? The Chatham House-YouGov Survey: British Attitudes Towards the UK's International Priorities. London: The Royal Institute of International Affairs, 2015, 48p.

ROSS, Tim. 'Ed Miliband under pressure to back air strikes in Syria'. The Daily Telegraph. 5 Oct 2014.

SCOTTISH NATIONAL PARTY. Stronger for Scotland: SNP Manifesto 2015. Edinburgh, Scottish National Party, 2015, 38p.

STRONG, James. 'Why Parliament Now Decides on War: Tracing the Growth of the Parliamentary Prerogative through Syria, Libya and Iraq', British Journal of Politics and International Relations, n/a, n/a, ISSN 1369-1481, 2014, pp.1-19.

UNITED NATIONS ORGANISATION. Resolution 1973 (2011). S/RES/1973 (2011). New York: Security Council. 17 Mar 2011.

WATT, Nicholas. 'Cabinet frustration over Syria vote as Cameron misreads Tory party's mood'. The Guardian. 30 Aug 2013.

WINTOUR, Patrick. 'Trident row: Cameron defends Fallon's attack on Miliband'. The Guardian. 9 Apr 2015.

---. ‘Ed Miliband: small-minded isolationism has damaged British influence'. The Guardian. 23 Apr 2015. 


\section{NOTES}

1. James STRONG, 'Why Parliament Now Decides on War: Tracing the Growth of the Parliamentary Prerogative through Syria, Libya and Iraq', British Journal of Politics and International Relations, n/a n/a, ISSN 1269-1481, 2014.

2. Adjournment debates are held at the end of each day's sitting. The government proposes to adjourn the House, the opposition objects, and MPs then discuss an issue proposed by an MP in advance. As they do not lead to a vote on the policy under scrutiny, governments need not fear being defeated. However, it also means that governments are free to ignore the content of debates and dismiss any opposition.

3. See for instance Rosara JOSEPH, The War Prerogative: History, Reform and Constitutional Design, Oxford: Oxford University Press, 2013, p. 78.

4. See for instance Mark BEVIR \& R. A. W. RHODES, 'Les récits du régime politique britannique', Revue française de science politique, vol. 49, n³, juin 1999, pp. 355-377.

5. James STRONG, op. cit., pp. 2-4.

6. HC Deb 21 Mar 2011, vol. 525, col. 799.

7. CABINET OFFICE, The Cabinet Manual: A guide to laws, conventions and rules on the operation of government, $1^{\text {st }}$ ed., London: Cabinet Office, 2011, para. 5.38.

8. UNITED NATIONS ORGANISATION, Resolution 1973 (2011), S/RES/1973 (2011), New York: Security Council, 17 Mar 2011, para. 4.

9. HC Deb 10 Mar 2011, vol. 524, col. 1066.

10. HC Deb 21 Mar 2011, vol. 525, col. 700-806.

11. Ibid., col. 709.

12. William HAGUE, interview, The Andrew Marr Show, BBC, 9 June 2013.

13. JOINT INTELLIGENCE ORGANISATION (CABINET OFFICE), 'Syria: Reported Chemical Weapons Use', Letter to the Prime Minister, 29 Aug 2013.

14. Peter DOMINICZAK, Tim ROSS \& Robert WINNETT, 'Cameron backs down on urgent Syria strikes', The Daily Telegraph, 28 Aug 2013. Available on line: <http://www.telegraph.co.uk/news/ worldnews/middleeast/syria/10272555/Cameron-backs-down-on-urgent-Syria-strikes.html>, accessed 13 May 2015.

15. HC Deb 29 Aug 2013, vol. 566 col. 1555-1556.

16. Nicholas WATT, 'Cabinet frustration over Syria vote as Cameron misreads Tory party's mood', The Guardian, 30 Aug 2013. Available on line: <http://www.theguardian.com/politics/2013/ aug/30/syria-vote-david-cameron>, accessed 13 May 2015.

17. Rowena MASON, 'Ed Miliband restores party confidence in his leadership on Syria motion', The Guardian, 30 Aug 2013. Available on line: <http://www.theguardian.com/politics/2013/ aug/30/syria-ed-miliband-labour-party-confidence-leadership>, accessed 13 May 2015.

18. Ben BRADSHAW, 'On Syria, we have allowed Labour policy to be dictated by the government', The Guardian, 5 Sep 2013. Available on line: <http://www.theguardian.com/commentisfree/2013/ sep/05/syria-labour-policy-dictated-by-government>, accessed 13 May 2015.

19. Tim BALE, Five Year Mission: The Labour Party under Ed Miliband, Oxford: Oxford University Press, 2015, pp. 189-191.

20. HC Deb 26 Sep 2014, vol. 585, col. 1255.

21. Tim ROSS, 'Ed Miliband under pressure to back air strikes in Syria', The Daily Telegraph, 5 Oct 2014. Available on line: <http://www.telegraph.co.uk/news/worldnews/islamic-state/11141395/ Ed-Miliband-under-pressure-to-back-air-strikes-in-Syria.html>, accessed 13 May 2015.

22. Ed MILIBAND, 'Britain's Place in the World: A Labour Perspective', speech, London, Chatham House, 24 April 2015. 
23. Ibid.

24. Patrick WINTOUR, 'Ed Miliband: small-minded isolationism has damaged British influence', The Guardian, 23 April 2015. Available on line: <http://www.theguardian.com/politics/2015/ apr/23/ed-miliband-small-minded-isolationism-damaged-british-influence>, accessed 13 May 2015.

25. LABOUR PARTY, Britain can be better: The Labour Party Manifesto 2015, London: Labour Party, 2015, pp.74-75.

26. Ibid., pp. 77-78.

27. HM GOVERNMENT, Securing Britain in an Age of Uncertainty: The Strategic Defence and Security Review, Cm 7948, London: The Stationery Office, 2010, para. 1.3.

28. HOUSE OF COMMONS DEFENCE COMMITTEE, The Strategic Defence and Security Review and the National Security Strategy, vol.1, HC 761, London: The Stationery Office, 2011, para. 85.

29. Andrew GRICE, 'Lib Dems push for "stand-by" Trident replacement deal', The Independent, 19 Jul 2012. Available on line: <http://www.independent.co.uk/news/uk/politics/lib-dems-pushfor-standby-trident-replacement-deal-7956987.html>, accessed 25 May 2015.

30. HM GOVERNMENT, Trident Alternatives Review, London: Cabinet Office, 2013.

31. LABOUR PARTY, Britain can be better, op. cit., p. 78.

32. SCOTTISH NATIONAL PARTY, Stronger for Scotland: SNP Manifesto 2015, Edinburgh: Scottish National Party, 2015, p. 20.

33. Patrick WINTOUR, 'Trident row: Cameron defends Fallon's attack on Miliband', The Guardian, 9 Apr 2015. Available on line: <http://www.theguardian.com/uk-news/2015/apr/09/trident-rowcameron-defends-fallons-attack-on-miliband>, accessed 13 May 2015.

34. Michael FALLON, 'This unholy alliance would put Britain's security in jeopardy', The Times, 9 Apr 2015. Available on line: <http://www.thetimes.co.uk/tto/opinion/thunderer/ article4405666.ece>, accessed 13 May 2015.

35. David CAMERON, speech, Cameron Direct event, Sherwood, 9 Apr 2015, quoted in Patrick Wintour, 'Trident row...', op. cit.

36. Defence and Security Election Debate, BBC Two, 28 Apr 2015.

37. HM GOVERNMENT, Securing Britain in an Age..., op. cit., paras. 2.D.3-2.D.5.

38. Liam FOX, interview with the author, 14 Jan 2015.

39. CONSERVATIVE PARTY, Strong Leadership, A Clear Economic Plan, A Brighter, More Secure Future: The Conservative Party Manifesto 2015, London: The Conservative Party, 2015, p. 75.

40. Ibid., p. 77.

41. Chatham House - YouGov Survey - General Public Results, Fieldwork dates 6-12 Aug 2014. The total sample size was 2,059 adults and was carried out online. Another survey focused on opinion-formers and was published under the title: Chatham House - YouGov Survey - OpinionFormer Results, Fieldwork Dates: 31 July - 16 Aug 2014. The total sample size was 704 adults. See also: Thomas RAINES, Internationalism or Isolationism? The Chatham House-YouGov Survey: British Attitudes Towards the UK's International Priorities, London: The Royal Institute of International Affairs, 2015.

42. YouGov Survey Results, Fieldwork: 23-24 April 2013. Similar results in YouGov/Sunday Times Survey Results, Fieldwork: 7-8 Mar 2013.

43. Michael FALLON, 'A Conservative Party View of UK Defence Policy', speech, Royal United Service Institute, London, 10 Apr 2015. Available on line: <https://www.rusi.org/events/past/ ref:E5506F525F0CF4/>, accessed 13 May 2015.

44. Chris GILES, 'Britain and the cuts: Blow for Cameron as UK faces deeper cuts', Financial Times, 10 Nov 2014. Available on line: <http://www.ft.com/cms/ s/2/5426fc12-6346-11e4-8a63-00144feabdc0.html\#axzz3If5MuzVT>, accessed 13 May 2015.

45. General Sir Nicholas HOUGHTON, interview, Andrew Marr Show, BBC, 9 Nov 2014. 
46. 'Nato $2 \%$ defence spending target should be met, MPs say', BBC News, 12 Mar 2015. Available on line: <http://www.bbc.com/news/uk-politics-31857044>, accessed 13 May 2015.

47. Ben FARMER, 'Obama to Cameron: maintain UK defence spending or weaken Nato', The Daily Telegraph, $10 \mathrm{Feb}$ 2015. Available on line: <http://www.telegraph.co.uk/news/worldnews/ barackobama/11403519/Obama-to-Cameron-maintain-UK-defence-spending-or-weaken-

Nato.html>, accessed 13 May 2015. See also US chief of staff General Raymond ODIERNO's concerns in Con COUGHLIN and Steven SWINFORD, 'US military chief: Britain cannot cut more troops', The Daily Telegraph, 1 March 2015. Available on line: <http://www.telegraph.co.uk/news/ uknews/defence/11443758/US-military-chief-Britain-cannot-cut-more-troops.html>, accessed 13 May 2015.

48. Michael FALLON, 'A Conservative Party View...', op. cit.

49. HOUSE OF COMMONS PUBLIC ADMINISTRATION SELECT COMMITTEE, Who does UK National Strategy?, HC 435, London: The Stationery Office, 2010, para. 39.

50. HOUSE OF COMMONS DEFENCE COMMITTEE, Towards the next Defence and Security Review: Part One, vol. 1, HC 197, London: The Stationery Office, 2014, paras 66-67.

51. Senior civil servants, interview with the author, Jan 2015.

52. 'National security strategy "will be rushed", BBC News, 3 Mar 2015. Available on line: <http://www.bbc.com/news/uk-politics-31703220>, accessed 13 May 2015.

53. HOUSE OF COMMONS DEFENCE COMMITTEE, The Strategic Defence and Security Review, HC 345, London: The Stationery Office, 2010, para. 30.

54. Ibid., para. 31 .

\section{ABSTRACTS}

This article aims to show that foreign and defence policy has played an unusual role in the debate between the main parties in the 2015 general election. Whereas, in the "Westminster model" tradition, there are few parliamentary debates on the issue, the consensus on foreign and defence policy has gradually disappeared, and the royal prerogative has been replaced by a parliamentary prerogative, with Parliament deciding on the use of armed forces abroad. This paper examines the arguments used by the Conservative-led coalition government and the Opposition about the conditions for interventions. The parliamentary debate is thus analysed as a prelude to the electoral debate. The latter focused on the consequences of a possible change of government, especially in case Labour had been led to form a government with the support of the SNP. But even if the Conservatives traditionally define themselves as the "party of defence", it is argued that domestic constraints, especially budgetary constraints, instead of a clear national strategy, now underpin Britain's foreign and defence policy.

Cet article cherche à montrer que la politique étrangère et de défense a joué un rôle inhabituel dans le débat entre les principaux partis lors des élections législatives britanniques de 2015. Alors qu'elle était traditionnellement l'objet de peu de débats au sein du Parlement, la politique étrangère et de défense est de moins en moins consensuelle, et la prérogative royale a cédé la place à une nouvelle prérogative parlementaire sur la question du déploiement des forces armées. Cet article examine les arguments du gouvernement de coalition et ceux de l'opposition concernant les conditions de tels déploiements, prélude au débat qui précéda l'élection du 7 mai 2015. Celui-ci s'est concentré sur les conséquences d'un potentiel changement de gouvernement, 
notamment si les Travaillistes étaient amenés à faire alliance avec le Scottish National Party. Mais si les Conservateurs se définissent traditionnellement comme le "parti de la défense », les contraintes, notamment budgétaires, qui pèsent sur le gouvernement, semblent guider une politique dont la direction stratégique est désormais peu claire.

INDEX

Mots-clés: politique étrangère, politique de défense, Trident, Strategic Defence and Security Review, National Security Strategy, David Cameron

Keywords: foreign policy, defence policy, Trident, Strategic Defence and Security Review, National Security Strategy, David Cameron

AUTHOR

THIBAUD HARROIS

Université Sorbonne Nouvelle - Paris 3 